\title{
ARTICLES
}

\section{THE RIGHT TO ACCESS TO A LAWYER AT POLICE STATIONS \\ Making the European Union Directive Work in Practice}

\author{
Ed CAPE ${ }^{*}$ and Jacqueline Hodgson ${ }^{* *}$
}

\begin{abstract}
Recent EU Directives provide for a range of procedural protections for suspects and accused persons, going beyond the more broadly articulated standards set out in the European Convention of Human Rights. These reforms are to be welcomed, but their implementation poses a range of challenges for Member States. Drawing on recent empirical research, this article focuses on one measure, the right to legal assistance during police custody. It discusses the range of complex and often inter-related factors that operate to help or to hinder the process of ensuring that the right is 'practical and effective' and not merely 'theoretical and illusory'. Member States do not share a common procedural tradition and alongside ensuring sufficient financial and human resources, effective implementation will require shifts in the legal and occupational cultures of police, prosecutors and the criminal bar.
\end{abstract}

Keywords: defence; police custody; procedural rights; suspects

\section{INTRODUCTION: THE EU 'ROADMAP’ OF PROCEDURAL RIGHTS}

In 2009 the European Union (EU) adopted a programme of reform of procedural rights of suspects and accused persons in criminal proceedings, known as the procedural rights 'roadmap'. In the context of extensive EU legislation regarding

\footnotetext{
University of the West of England, Bristol, UK.

** School of Law, University of Warwick, UK.

1 Roadmap with a view to fostering protection of suspect and accused persons in criminal proceedings, 1 July 2009, 11457/09 DROIPEN 53 COPEN 120.
} 
judicial and police co-operation between EU Member States, and measures facilitating prosecution and mutual enforcement of court judgments, it was argued that fostering the protection of procedural rights would facilitate mutual recognition by enhancing mutual trust, and would increase the confidence of citizens in the ability of the EU to protect and guarantee their rights. ${ }^{2}$ Previous attempts to adopt EU-wide measures to protect procedural rights had foundered as a result of the need for unanimity amongst Member States, ${ }^{3}$ but fresh impetus was provided by two developments. First, in November 2008 the Grand Chamber of the European Court of Human Rights (ECtHR), in the case of Salduz v Turkey, ${ }^{4}$ held that suspects arrested by the police are entitled, under Article 6(3) of the European Convention on Human Rights (ECHR), to access to a lawyer before their first interrogation. ${ }^{5}$ Second, anticipated adoption of the Lisbon Treaty, ${ }^{6}$ which came into force in December 2009 five months after the roadmap was adopted, would see the introduction of qualified majority voting, meaning that no single Member State could veto legislation in this area. ${ }^{7}$

The procedural rights roadmap established a five year programme of legislation designed to establish minimum standards in respect of five key procedural rights: interpretation and translation (Measure $\mathrm{A}$ ); information about procedural rights and about the suspected or alleged offence (Measure B); legal advice and legal aid (Measure C); communication with relatives, employers and consular authorities (Measure D); and special safeguards for vulnerable persons (Measure E) ${ }^{8} \mathrm{~A}$ Directive on the right to interpretation and translation was adopted on 20 October 2010, with a transposition date $^{9}$ of 27 October $2013 .{ }^{10}$ This provides that suspected or accused persons who do

2 The principle of mutual recognition requires national measures, such as the court judgment of a European Union Member State, to be recognized by, and to have the same or similar effects in all other Member States. See further J. Hodgson, 'Safeguarding Suspects' Rights in Europe: A Comparative Perspective' (2011) 14 New Criminal Law Review 611, 617.

3 Despite considerable support from some Member States and NGOs and other organisations across the EU, opposition from the UK, together with Ireland and the Czech Republic, meant that the proposed framework decision on procedural rights could not be adopted.

4 ECtHR 27 November 2008, No. 36391/02.

5 Subsequent decisions of the ECtHR made it clear that this included the right to have a lawyer present during police interrogations. See, for example, ECtHR 21 June 2011, Mader v Croatia, No. 56185/07, and ECtHR 28 June 2011, Sebalj v Croatia, No. 4429/09.

6 Treaty of Lisbon amending the Treaty on European Union and the Treaty establishing the European Community, signed at Lisbon, 13 December 2007, 2007/C 306/01. For the consolidated versions of the treaties as amended by the Treaty of Lisbon, see the Treaty on European Union (TEU) and the Treaty on the Functioning of the European Union (TFEU), No. 2008/C 115/01, Official Journal of the European Union, C 115, Volume 51, 9 May 2008.

7 For a more detailed account, see E. Cape and Z. Namoradze, Effective Criminal Defence in Eastern Europe (Moldova: Soros Foundation, Moldova, 2012), ch. 1.

8 In addition, the roadmap provided for a Green Paper to be published on the right to review of the grounds for detention.

9 That is, the date by which Member States must bring into force laws, regulations and administrative provisions necessary to comply with the Directive.

10 Directive 2010/64/EU of the European Parliament and of the Council of 20 October 2010 on the Right to Interpretation and Translation in Criminal Proceedings. 
not speak or understand the language of the proceedings are provided with interpretation, including during police questioning, and with translations of essential documents, including any decision depriving them of their liberty and of any charge. ${ }^{11}$ A Directive on the right to information was adopted on 22 May 2012, with a transposition date of 2 June 2014. ${ }^{12}$ This provides for three discrete rights: the right to information about procedural rights, including a written 'Letter of Rights' for persons arrested or detained; ${ }^{13}$ the right to be provided with information about the reasons for arrest or detention, and about the accusation, before the first official police interview; ${ }^{14}$ and the right of access to case materials. ${ }^{15}$ The latter includes the right to be provided with documents that are essential to challenging effectively the lawfulness of the arrest or detention, ${ }^{16}$ and the right to be provided with all material evidence in the possession of the competent authorities (whether for or against the suspect or accused) no later than submission of the merits of the accusation to the judgment of a court. ${ }^{17}$ Measure $\mathrm{C}$ was split, and provisions regarding the right of access to a lawyer, and the Measure $\mathrm{D}$ provisions regarding communication with third parties, were incorporated into one Directive, which was adopted on 22 October 2013, with a transposition date of 27 November 2016. ${ }^{18}$ Broadly, the Directive provides for a right of access to a lawyer to all suspected and accused persons, including before and during questioning by the police. ${ }^{19}$ The remaining measures in the roadmap, including the legal aid provisions

11 See, in particular, Articles 2 and 3. In England and Wales, the provisions of the Directive applicable to persons in police custody were given effect by amendments to PACE Codes of Practice C and H, brought into effect on 27 October 2013 by the Police and Criminal Evidence Act 1984 (Codes of Practice) (Revisions to Codes A, B, C, E, F and H) Order 2013 SI No. 2685.

12 Directive 2012/13/EU of the European Parliament and of the Council of 22 May 2012 on the right to information in criminal proceedings.

13 Articles 3 and 4 of the Directive on the right to information.

14 Article 6 and Recital 28 of the Directive on the right to information.

15 Article 7 of the Directive on the right to information.

16 Article 7(1) of the Directive on the right to information, which must be made available at the latest before a competent judicial authority is called to decide upon the lawfulness of the arrest or detention, and in due time to allow the effective exercise of the right to challenge the lawfulness of the arrest or detention (Recital 30).

17 Article 7(2) and (3). Timing of the provision of material evidence is subject to the objective of safeguarding the fairness of the proceedings and to enable the preparation of the defence (Art $7(2))$. Article 7(4) provides for derogation from Article 7(2) and (3), but not Article 7(1), if access to the materials may lead to a serious threat to the life or the fundamental rights of another person, or if refusal is strictly necessary to safeguard an important public interest, but only provided that this does not prejudice the right to a fair trial. In England and Wales, the provisions of the Directive applicable to persons in police custody were given effect by amendments to PACE Codes $\mathrm{C}$ and $\mathrm{H}$, brought into effect on 2 June 2014 by the Police and Criminal Evidence Act 1984 (Codes of Practice) (Revisions to Codes C and H) Order 2014 SI No. 1237.

18 Directive 2013/48/EU of the European Parliament and of the Council of 22 October 2013 on the right of access to a lawyer in criminal proceedings and in European arrest warrant proceedings, and on the right to have a third party informed upon deprivation of liberty and to communicate with third persons and with consular authorities while deprived of liberty.

19 Under Protocol 21, Articles 1 to 3, of the Lisbon Treaty the UK, along with Ireland, is not bound by a Directive issued under Title V of Part Three of the TFEU unless it opts-in. The UK government has 
of Measure C, are the subject of a number of proposed Directives and Commission Recommendations, which were issued in November 2013 and which are currently the subject of negotiations. ${ }^{20}$

Whilst the ECHR has proved to be the most effective international system of human rights protection ever developed, ${ }^{21}$ its effect in establishing procedural standards is limited by the fact that ECtHR jurisprudence is essentially reactive (depending upon the cases brought before it), its decisions are based upon the particular facts of those cases, and enforcement mechanisms are relatively weak. This means that the standards established are neither detailed nor comprehensive. In the absence of rational, strategic responses to ECtHR decisions by the governments of signatory states, this can result in unplanned and haphazard application of such decisions to national legal systems. For example, the decision of the UK Supreme Court in Cadder v HM Advocate in October 2010, ${ }^{22}$ which held that Scottish law on the right of access to a lawyer for people detained by the police did not comply with Salduz, led to the adoption three days later of legislation introducing such a right. ${ }^{23} \mathrm{In}$ France, legislation extending the scope of the right of access to a lawyer, from simply pre-interrogation advice to presence during the interrogation of the suspect, was prompted by a constitutional challenge to the existing criminal procedure - a challenge inspired by the Salduz decision. ${ }^{24}$ The Constitutional Council gave the government one year to put in place the necessary changes. The legislation was due to come into force in June 2011, ${ }^{25}$ but this was pre-empted by a decision of the Grand Chamber of the Cour de Cassation two months earlier, ${ }^{26}$ holding that as the ECtHR

opted in to the Directive on the right to interpretation and translation, and the Directive on the right to information, but has not opted-in to the Directive on the right of access to a lawyer.

20 The proposed Directive on provisional legal aid for suspects and accused persons deprived of liberty (COM (2013) 824), and proposed Recommendation on the right to legal aid for suspects or accused persons in criminal proceedings (C (2013) 8179/2); and the proposed Directive on procedural safeguards for children suspected or accused in criminal proceedings (COM (2013) 822/2), and proposed Recommendation on procedural safeguards for vulnerable persons suspected or accused in criminal proceedings (C (2013) 8178/2). In addition, the Commission issued a proposed Directive on the strengthening of certain aspects of the presumption of innocence and of the right to be present at trial in criminal proceedings (COM (2013) 821/2).

21 See, for example, the speech of Mr. Wildhaber, President of the ECtHR, on the occasion of the opening of the Judicial Year in 2006.

22 [2010] UKSC 43.

23 Criminal Procedure (Legal Assistance, Detention and Appeals) (Scotland) Act 2010 was passed by the Scottish Parliament on 27 October 2010, the day after the Supreme Court decision, and received Royal Assent two days later, and had immediate effect. See further, J. Blackstock, E. Cape, J. Hodgson, A. Ogorodova and T. Spronken, Inside Police Custody: An Empirical Account of Suspects' Rights in Four Jurisdictions (Antwerp: Intersentia, 2014), pp. 119-120.

24 Decision No. 2010-14/22 QPC, 30 July 2010.

25 Law No. 2011-392 of 14 April 2011.

26 Cass. Ass. Plen., 15 April 2011, Nos. 10-30.316, 10-30.313, 10-30.242 \& 10-17.049. See further, in respect of developments in France and Scotland, P. Ferguson and F. Raitt, 'A Clear and Coherent Package of Reforms? The Scottish Government Consultation Paper on the Carloway Report' (2012) 
had clearly ruled on the subject, the right of access to a lawyer was applicable with immediate effect. In the Irish case of DPP $v$ Gormley, the Supreme Court held that the pre-trial investigation at the police station attracted the same constitutional protections as the trial, ruling that the incriminating statements made to the police in the absence of a lawyer (where the suspect had requested legal advice but was interviewed before the lawyer arrived at the police station) were inadmissible. ${ }^{27}$ In May 2014 the Director of Public Prosecutions unilaterally, and without prior consultation, directed that the Garda were in future to permit solicitors to attend police interviews. $^{28}$

The EU roadmap, by contrast, is an attempt to establish a coherent set of procedural rights and standards, and each Directive introduced so far gives Member States three years ${ }^{29}$ to consider and then introduce the laws, procedures and mechanisms necessary to implement its provisions. Research in England and Wales following the introduction of the Police and Criminal Evidence Act (PACE) 1984, in particular on the right of access to a solicitor, ${ }^{30}$ and later research on access to effective criminal defence in a wide range of European jurisdictions, ${ }^{31}$ demonstrated that in order for procedural rights to be effective, relevant laws need to be complemented by both regulations and procedures that enable those rights to be 'practical and effective', ${ }^{22}$ and also consistent levels of competence amongst legal and criminal justice professionals underpinned by

Criminal Law Review 909, and D. Giannoulopoulos, "North of the Border and Across the Channel”: Custodial Legal Assistance Reforms in Scotland and France' (2013) Criminal Law Review 369.

27 DPP v Gormley [2014] IESC 17. “... the right to a trial in due course of law encompasses a right to have early access to a lawyer after arrest and the right not be interrogated without having had an opportunity to obtain such advice. The conviction of a person wholly or significantly on the basis of evidence obtained contrary to those constitutional entitlements represents a conviction following an unfair trial process" (paragraph 9.13 of the judgment).

28 See D. Robinson, Guest post: Improved access to a lawyer in Ireland, 14 May 2014, available via www. fairtrials.org/press/page/5/ (last accessed on 19 November 2014).

29 The transposition date for each Directive introduced so far is three years after the date the Directive came into force.

30 See, for example, A. Sanders, L. Bridges, A. Mulvaney and G. Crozier, Advice and Assistance at Police Stations and the 24 Hour Duty Solicitor Scheme (London: Lord Chancellor's Department, 1989); M. McConville and J. Hodgson, Custodial Legal Advice and the Right to Silence (London: HMSO, 1993); and M. McConville, J. Hodgson, L. Bridges and A. Pavlovic, Standing Accused: The Organisation and Practices of Criminal Defence Lawyers in Britain (Oxford: Clarendon Press, 1994).

31 See, for example, E. Cape, J Hodgson, T. Prakken and T. Spronken, Suspects in Europe: Procedural Rights at the Investigative Stage of the Criminal Process in the European Union (Antwerp: Intersentia, 2007); E. Cape, Z. Namoradze, R. Smith and T. Spronken, Effective Criminal Defence in Europe (Antwerp: Intersentia, 2010); E. Cape and Z. Namoradze op. cit.; and S. Schumann, K. Bruckmuller and R. Soyer, Pre-trial Emergency Defence: Assessing pre-trial access to legal advice (Antwerp: Intersentia, 2012).

32 This is the formula adopted by the ECtHR to procedural rights under the ECHR, Article 6. See, for example, ECtHR 9 October 1979, Airey v Ireland, No 6289/73; ECtHR 13 May 1980, Artico v Italy, No. 6694/74; ECtHR 9 October 2008, Moiseyev v Russia, No. 62936/00; and ECtHR 24 September 2009, Pishchalnikovv Russia, No. 7025/04. 
appropriate professional cultures. ${ }^{33}$ Thus an important question that arises in respect of the EU procedural rights roadmap is what do Member States, as well as relevant stakeholders such as the police and bar associations, need to do in order to ensure that the EU Directives, and in particular the Directive on the right of access to a lawyer, are 'practical and effective' and not merely 'theoretical and illusory'? ${ }^{34}$ Drawing on our own recent empirical comparative study, this is the question we set out to address here.

\section{RESEARCHING PROCEDURAL RIGHTS IN EUROPE}

Empirical research on the effectiveness of safeguards for suspects detained and questioned by the police was conducted in England and Wales in the $1990 \mathrm{~s}^{35}$ and in France some years later, ${ }^{36}$ but there has been a real dearth of comparative empirical studies of the day-to-day implementation of procedural safeguards for suspects. The Inside Police Custody project goes some way to addressing this gap in our knowledge of pre-trial criminal justice. Funded by the European Commission, it is a comparative empirical study of four EU jurisdictions: England and Wales, France, the Netherlands and Scotland. ${ }^{37}$ Carried out between 2011 and 2013, the research consisted of gathering detailed information about the law and practices in each country, followed by observational fieldwork in police stations and with lawyers in law firms, and interviews of lawyers and police officers. ${ }^{38}$ We selected two field sites in each jurisdiction - one based on a busy police station and the other on a less busy police station. The study was a major undertaking, working with both police and lawyers in eight main field sites across four jurisdictions, producing a large amount of rich qualitative data gathered over the equivalent of one and a half researcher years. In this paper, we focus on the challenges of implementing the right to legal assistance, but the project also

33 J. Blackstock et al. op. cit., p. 425

34 ECtHR 13 May 1980, Artico v Italy, No. 6694/74, para. 33.

35 See the studies cited above, n. 30. For more recent studies see L. Skinns, Police Custody: Governance, legitimacy and reform in the criminal justice process (Abingdon: Willan, 2011); and P. Pleasence, V. Kemp and N. Balmer, "The Justice Lottery? Police Station Advice 25 Years on from PACE”, (2011) Criminal Law Review 3.

36 J. Hodgson, French Criminal Justice (Oxford: Hart, 2005); J. Hodgson, (2004) “The detention and interrogation of suspects detained in police custody in France: a comparative account” European Journal of Criminology 1(2) 163-99; J. Hodgson, (2002) "Suspects, Defendants and Victims in the French Criminal Process: the Context of Recent Reform" International and Comparative Law Quarterly 51(4) 781-815. See also S. Field and A. West, (2003) "Dialogue and the Inquisitorial Tradition: French Defence Lawyers in the Pre-Trial Criminal Process" Criminal Law Forum 14(3) 261-316.

37 The study 'Procedural rights of suspects in police detention in the EU: empirical investigation and promoting best practice' JUST/2010/JPEN/AG/1578 was funded by the European Commission, and published as J. Blackstock et al., op. cit.

38 For a full account of the research methodology, see further J. Blackstock et al., op. cit., ch. 2. 
examined the suspect's right to information, to interpretation and translation, and the right to silence during police interrogation.

In the field, researchers spent time with police officers responsible for booking in suspects, notifying them of their rights, and contacting lawyers and interpreters, as well as those carrying out the interrogation of suspects. The researchers were also able to consult case files and custody records and to discuss these with the officers concerned. Observations of lawyers were organised to reflect local arrangements in place for the provision of custodial legal advice. In England and Wales, where law firms specialise in criminal work, and where lawyers are often called to the police station by existing clients, as well as in their capacity as duty lawyers, researchers were based with individual firms of solicitors. In France and the Netherlands, where firms are less specialised and have a much smaller stream of police station work, researchers attached themselves to duty lawyer schemes, accompanying different lawyers each day, according to who was on duty. ${ }^{39}$ In all cases, we were able to spend some time talking informally with lawyers about their work, their approach to custodial legal advice and about their relationships with officers.

Most data was recorded in the form of a field diary, but pro-formas were also completed for each case observed with the police and with lawyers. ${ }^{40}$ In total, researchers spent 78 weeks carrying out observations. We were not granted the same access in each jurisdiction. In France, we were able to accompany lawyers and to observe consultations and interrogations, but we were not permitted to be based in the police station with officers. In Scotland, we were able to observe police officers booking in suspects, but we were not permitted to attend interrogations. We also had difficulties gaining access to lawyers' firms in Scotland, although we did spend some time observing Scottish Legal Aid Board (SLAB) Solicitor Contact Line lawyers. In England and Wales, and in the Netherlands, we were granted more or less full access. Ninety four interviews were conducted with police officers and lawyers across the four jurisdictions.

This methodology enabled us to observe the daily practices of police officers and lawyers, and to identify features of legal procedures, occupational cultures and resource constraints that underpin different behaviours. By understanding the implementation of suspects' rights from multiple perspectives and across different jurisdictions, we were able to gain deeper insights into the practical constraints upon working practices and so evaluate the effectiveness of the right of access to a lawyer provided to suspects detained and questioned in police custody, and also to make practical recommendations for improvement. ${ }^{41}$ In this paper, we draw on this data

39 In Scotland, we were able to negotiate only very limited access to lawyers. See J. Blackstock et al., op. cit. pp. 59-60.

40384 of these case records were completed overall.

41 Whilst effectiveness may be understood slightly differently in different criminal procedures, it is here contrasted with the ineffectiveness of rights that exist on paper only, or the implementation of which is hampered by the working practices of other actors or by insufficient resources. For our 
and earlier research studies, to consider the practical changes needed to ensure compliance with the Directive, and the likely obstacles that Member States will face.

\section{INFORMING SUSPECTS OF THE RIGHT OF ACCESS TO A LAWYER}

Although the roadmap Directives have been legislated separately on a step-by-step basis, they are closely connected in terms of providing procedural protections for suspects. The Directive on the right to information ${ }^{42}$ provides that suspects who are arrested or detained must be notified, orally and in writing (by means of a "Letter of Rights"), of the right of access to a lawyer, and any entitlement to free legal advice and the conditions for obtaining such advice. ${ }^{43}$ The information must be provided in simple and accessible language, taking into account the particular needs of those who are vulnerable, and the Letter of Rights must normally be written in a language that the suspect understands. ${ }^{44}$ The suspect must be given the opportunity to read the Letter of Rights, and allowed to keep it in their possession throughout the time that they are deprived of their liberty. ${ }^{45}$ These provisions are clearly designed to ensure that suspects are given information, inter alia, about their right of access to a lawyer in a form that they are capable of understanding. However, they do not go as far as the ECtHR jurisprudence, which requires the relevant authorities to take all reasonable steps to ensure that the suspect is fully aware of their rights and, as far as possible, understands the implications of waiving them. ${ }^{46}$

The process by which suspects are informed of their right of access to a lawyer is key to understanding their decisions whether or not to exercise the right. If the suspect thinks that requesting a lawyer will lead to delay, or will have an adverse impact on the case, for example, they may be reluctant to ask for legal assistance. ${ }^{47}$ On the other hand, if they are told that the right is available to all suspects free of charge, and that

conclusions and recommendations generally, see J. Blackstock et al., op. cit. ch. 9, and also the “Training Framework on the Provision of Suspects' Rights" at Annex 1.

42 Op. cit.

$43 \quad$ Articles 3 and 4.

44 If a Letter or Rights in the appropriate language is not available a suspect or accused person may, as an interim measure, be informed of their rights orally in a language that they understand (Article 4(5)).

45 Article 4(1).

46 See, for example, ECtHR 11 December 2008, Panovits v Cyprus, No. 4268.04, paras. 67-68; ECtHR 31 March 2009, Plonka v Poland, No. 20310/02, paras. 37-38; and ECtHR 24 September 2009, Pishchalnikov $v$ Russia, No. 7025/04, paras. 79-80.

47 In our research we found that a major concern of suspects was to be released from police custody as quickly as possible, and that their decision on whether to consult a solicitor often appeared to depend on their perception of how long the detention process would take and, in particular, whether they were likely to be granted bail (J. Blackstock et al., op. cit., p. 275). 
no interrogation will commence before they have had an opportunity to consult with the lawyer, the right looks rather more appealing.

Research in England and Wales in the early period following introduction of the right of access to a lawyer found that the police preferred suspects not to have access to a lawyer, and so employed a range of tactics designed to dissuade them from exercising their right to custodial legal advice. These included failing to tell suspects that advice was free at the point of delivery; telling suspects that requesting a lawyer would result in them spending longer in custody; and telling suspects that they did not need a lawyer if they had nothing to hide, or if the case was straightforward. ${ }^{48}$ This is no longer the hallmark of police practice in England and Wales. In part, this is the result of changes to the PACE 1984 Code of Practice C, which makes it clear that officers should not engage in these types of ploys. ${ }^{49}$ However, our research indicates that there has also been a change in police culture. ${ }^{50}$ Lawyers are still regarded as adversaries to some extent, but the spectre of silent suspects and collapsed investigations as a result of legal advice never materialised. The role of the lawyer at the police station (or their presence, at least) has gained a degree of acceptance over time, and one consequence of this is that suspects are now normally informed of their right of access to a lawyer in neutral terms. It is important to bear this chronology in mind when comparing countries at different stages of the introduction, or the strengthening, of the right of access to a lawyer. Laws may be similar across countries, but it can take many years for legal practices and professional cultures to change and to re-establish themselves.

In the Netherlands, we observed officers dissuading suspects from taking up their right to custodial legal advice, adopting similar ploys to those observed in England and Wales in the early years following the introduction of the right of access to a lawyer. Given that suspects' primary objective is often to secure their release from police custody as soon as possible, they are not always attentive to what is being said to them concerning their rights, especially if they have been detained before. This is

48 A. Sanders and L. Bridges, (1990) “The Right to Legal Advice and Police Malpractice", Criminal Law Review 494; M. McConville, A. Sanders and R. Leng, The Case for the Prosecution (London: Routledge, 1991); M. McConville and J. Hodgson op. cit.; and M. McConville, J. Hodgson, L. Bridges and A. Pavlovic, op. cit. For more recent research, see V. Kemp, (2013) “'No Time for a Solicitor': Implications for Delays on the Take-up of Legal Advice”, Criminal Law Review 184.

49 For example, Code of Practice $\mathrm{C}$ provides that no police officer should do or say anything with the intention of dissuading a detainee from obtaining legal advice (para. 6.4). The Code has recently been amended to provide that a police officer must not, except to answer a direct question, indicate to a suspect that the period for which they are liable to be detained might be reduced if they do not ask for legal advice or do not want a solicitor present when they are interrogated (Code C, Note for Guidance 6ZA).

50 Generally, custody officers performed their tasks in a "polite, professional and friendly way... making extra efforts if the suspect did not seem to understand what they were told or asked" (J. Blackstock et al., op. cit., p. 220). See also L. Skinns, op. cit., ch. 5; and V. Kemp and N. Balmer, Criminal Defence Services: Users' Perspectives, Research Paper No. 21 (London: Legal Services Research Centre, 2008). 
further aggravated when suspects are under the influence of alcohol or drugs - a common occurrence in the cases we observed. We saw evidence of the police in Scotland and the Netherlands using this to their own advantage, suggesting that the suspect's release would be delayed if they have to wait for the lawyer to arrive. In France, the absence of a consistent mode of delivery of information about procedural rights meant that suspects were not actively dissuaded from exercising their rights, but lacked the information necessary to make a rational, informed decision. The police are required to inform suspects that they have a right to a lawyer before and during interrogation, but they are unlikely to tell suspects that this is free, that any consultation will be in private, and that the right is a continuing one throughout the period of detention. ${ }^{51}$ The 2013 Report of the Contrôleur Général des lieux de privation de liberté5 $e^{52}$ also noted that suspects did not always realise that the right to legal advice and assistance meant the right to have a lawyer present with them at the police station, nor that this advice may be provided free of charge.

There are a number of factors to consider when informing suspects of their rights if they are to make a considered and informed choice: whether rights are given orally or in writing; the point at which suspects are told of their rights; the point at which suspects must respond to their rights; whether rights are explained in language that is readily understood by the suspect; and the level of detail that is provided to enable suspects to exercise their rights, such as information about the right to contact family members, to an interpreter, or information about duty lawyers. The procedures in place for providing this information to suspects affect both their ability to understand and to exercise their rights.

We found that some of the jurisdictions in the study did not have a standard procedure for the administration of rights, and that responsibility for providing this information did not rest with a designated individual. As a result, the procedure by which suspects were informed of their rights depended on the individual police officer concerned in the case. In these circumstances, information on suspects' rights may be delayed or be delivered in an incomplete way. In the Netherlands, for example, responsibility for notifying suspects of their rights was divided between the assistant prosecutor (so-called, but who is in fact a senior police officer) and the arresting officer. They were not located in the same place and each often assumed that the other had spoken to the suspect, with the result that the notification of rights was sometimes delayed and often incomplete. In England and Wales, legal regulation of the notification process has been developed and refined over some 30 years. The PACE Code of Practice, in particular, was adapted in response to research findings that the police engaged in strategies of rights avoidance. ${ }^{53}$ The Letter of Rights in England and

\footnotetext{
$51 \quad$ Standardised information has been available in France since March 2013, but the language is very formal.

52 Rapport d'activité pour l'année 2013 at p. 273.

53 See n. 48 and related text.
} 
Wales (known as the Notice of Rights and Entitlements) now provides an example of good practice. ${ }^{54}$ The custody officer may customise the way that they notify suspects of their rights, adapting the official language or providing more detail, but the same core information must be included as a minimum. ${ }^{55}$ Scotland also had a formal procedure for notification of rights (the 'SARF' form), ${ }^{56}$ but far from being an example of good practice, this is problematic for both police officers and suspects. In particular, it is repetitious and employs language that is difficult to understand. For example, it requires suspects to be told that they may "have intimation sent to a solicitor". As one police officer explained to us in interview, these are not everyday words but "dictionary" words. ${ }^{57}$ The procedure also requires suspects to be asked "Do you want to exercise your right of access to a lawyer later?" - an almost impossible question to answer. This was frustrating for suspects who did not understand what was being read out to them and for officers, who felt that they could not deviate from the 'script' in order to make the rights more comprehensible.

Other than in England and Wales, suspects were very unlikely to be told that their rights are continuing and that they may change their mind at any time. This is especially important with regard to waiver of the right to legal assistance as suspects often have insufficient information (and insufficient time) to make an informed choice at the moment when they are asked whether or not they want a lawyer. Those who do waive their right to a lawyer are likely to do so with insufficient understanding of the nature and scope of the right and so the consequences of exercising it or not. As one Scottish lawyer explained to us:

There's a big problem about waiver... My view is that the SARF process is inadequate. It doesn't tell them about legal aid; it doesn't tell them there can be advice by telephone. It doesn't tell them, actually, that the solicitor can be present at interview... There's some interesting things about the actual timing of the SARF procedure, when the form is actually signed by the suspect, and there's no attempt at all by the police, because they're not required to on the form, to check what it is that they understand [and] what it is that they're giving up. ${ }^{58}$

Another relevant feature in the notification of suspects' rights (and indeed in many aspects of the treatment of suspects in police custody across all four jurisdictions in our study) is the prior experience of the suspect. Police officers repeatedly told us that

\footnotetext{
$54 \quad$ See T. Spronken, An EU-Wide Letter of Rights (Antwerp: Intersentia, 2010), especially p. 36. Note that the Notice of Rights and Entitlements was amended as from 2 June 2014, together with associated revisions to Code of Practice C, to take account of the EU Directive on the right to information (see the Police and Criminal Evidence Act 1984 (Codes of Practice) (Revisions to Codes C and H) Order 2014 SI No. 1237).

55 J. Blackstock at al., op. cit., p. 228.

56 SARF, the Solicitor Access Recording Form.

57 J. Blackstock at al., op. cit., pp. 230-34.

58

IScotSlab3.
} 
they would tailor the notification process according to whether the suspect had been detained before, or this was their first time in police custody. Prior experience of custody was also relevant to the suspect's decision to request a lawyer, but in often contradictory ways. Those with little or no experience of police custody were more likely to underestimate the importance of a lawyer, or to fail to understand the nature and extent of the right. Where the right was better understood, suspects with no prior experience were more likely to request advice as they did not know what to expect. Suspects who had experience of arrest and detention procedures were more likely to adopt a set position: either they always requested a lawyer, or they felt that they had sufficient understanding of the procedure to deal with police questioning alone.

\section{DELIVERING LEGAL ADVICE AND ASSISTANCE}

In order for the right of access to a lawyer to be effective, suitably qualified and experienced lawyers need to be willing and able to provide assistance to suspects when and where that assistance is required. To cater for suspects who have not previously used, or do not know of, a suitable lawyer or where the nominated lawyer is unavailable, a duty lawyer scheme needs to be in place, so that a lawyer is available to provide advice and assistance at short notice. Such arrangements should take into account the fact that demand for legal advice and assistance is unpredictable and often occurs outside of office hours, and that legal assistance needs to be delivered promptly.

Whilst the Directive on access to a lawyer places responsibility on Member States to ensure that suspects have "the right of access to a lawyer in such time and in such a manner so as to allow the persons concerned to exercise their rights of defence practically and effectively", ${ }^{59}$ apart from the requirement to guarantee confidentiality of lawyer/client communications, ${ }^{60}$ it leaves it to Member States to determine how this is to be achieved. ${ }^{61}$ The EU Directive on interpretation and translation requires Member States to take concrete measures to ensure the quality of interpretation and translation, ${ }^{62}$ and to encourage appropriate training, ${ }^{63}$ but there are no similar provisions in the Directive on the right of access to a lawyer. ${ }^{64}$

61 Article 13 does provide that the particular needs of vulnerable suspects are to be taken into account in the application of the Directive, but gives no indication of what special provisions should be made.

62 Article 5.

63 Article 6.

64 This may be contrasted with the United Nations Principles and Guidelines on Access to Legal Aid in Criminal Justice Systems, adopted by the UN General Assembly on 20 December 2012, which provides that States should put in place mechanisms to ensure the competence of legal aid providers (Principle 13).
} 
The law in each of the four jurisdictions in the study was broadly compliant with both ECtHR jurisprudence and the EU Directive. In each jurisdiction the law provided for a right of access to a lawyer by a suspect in police custody, free of charge, ${ }^{65}$ and within a reasonable time following arrest ${ }^{66}$ and detention. In England and Wales, France and Scotland, this included the right to have a lawyer present during police interrogations, although in the Netherlands this right was restricted to juveniles and to suspects arrested on suspicion of certain serious offences. In this respect, the law in the Netherlands does not comply with the case-law of the ECtHR, ${ }^{67}$ and in any event will have to be amended by the time that the Directive comes into effect in 2016. In France and the Netherlands there are also restrictions on the provision of legal advice and assistance; in both jurisdictions the police are only required to wait for a maximum of two hours for arrival of a lawyer before commencing interrogation, and the lawyer/client consultation is limited to 30 minutes (and in France, only one consultation is normally permitted). Whilst in each jurisdiction approximately half of detained suspects asked for a lawyer (except that in France it was estimated that between one third and one half did so), ${ }^{68}$ the extent to which they received legal assistance and the way in which it was provided differed significantly. In England and Wales, and France, in all observed cases where legal assistance was provided the lawyer attended the police station to advise the suspect in person. In the Netherlands, this was also normally the case although, as a result of the restriction noted above, in most cases the lawyer could only provide pre-interrogation advice. In Scotland, however, personal attendance was the exception. Scottish Legal Aid Board statistics (confirming our research findings) show that in the two years from July 2011, in only one in eight cases where legal advice was provided was it provided in person, in the remainder of cases advice being provided exclusively by telephone. ${ }^{69}$

Given that the legal entitlement to custodial legal advice was broadly similar in all four jurisdictions (except for the restriction on presence during police interrogations in the Netherlands), what may explain the differences in the delivery of legal advice and assistance? Our research found an interconnected set of factors, including the professional cultures of defence lawyers which, in turn, were linked to procedural

65 Although in Scotland, police station legal aid is subject to a means test.

66 In Scotland, the right applies to a person in police detention under the Criminal Justice (Scotland) Act 1995, s. 14, as distinct from a person under arrest, although detention under this provision would amount to an arrest for the purposes of the ECHR, Articles 5 and 6(3).

67 See n. 5.

68 The research was not designed to capture this information in a way that could be generalised. In England and Wales, only one third of observed suspects requested a lawyer, but other studies have found the request rate to be significantly higher (V. Kemp and N. Balmer, op. cit., found a request rate of between 54 and 59\%, and L. Skinns, op. cit., p. 113, found that $60 \%$ of detained suspects requested a lawyer. In the other three jurisdictions, the request rate reported was based on cases observed and/or on interviews with police officers and lawyers.

69 Scottish Legal Aid Board, Police Station Duty Scheme Update - Solicitor Contact Line, July 2014, available via www.slab.org.uk/news/archive/articles/July_Duty_Scheme_1407722400016.html (last accessed 19 November 2014). 
traditions generally and police disclosure practices specifically. It is also significant that each jurisdiction was at a different stage in its development of custodial legal advice. Lawyers have been advising suspects before and during police interrogations in England and Wales for some 30 years, whereas this was a very recently introduced safeguard in Scotland and the Netherlands. In France, lawyers have been providing pre-interrogation advice for nearly 15 years, but have only recently been permitted to attend interrogations. Police and lawyers were, therefore, at very different stages in terms of negotiating relationships of trust and the respective parameters of their roles. These broader factors are examined below, but we first examine some more practical influences relating to the structure and organisation of law firms, remuneration, and the ways in which duty lawyer schemes are organised.

In the first decade following introduction of the right to consult a solicitor in England and Wales (by the PACE 1984, s. 58), research showed that many of the problems now being encountered in other countries were also experienced in this jurisdiction: difficulties in providing advice promptly, lack of expertise, over-use of telephone advice, and a passive approach to advising suspects at police stations. ${ }^{70}$ However, encouraged by the Legal Aid Board and its successor, the Legal Services Commission, solicitors' firms carrying out legally-aided criminal defence work reduced in number and became more specialised, and the criminal legal aid contract introduced at the turn of the century included minimum requirements regarding attendance at police stations, training and supervision, and participation in the police station duty solicitor scheme. ${ }^{71}$ Together with the ability to employ formally trained non-solicitors - accredited representatives - to provide police station legal advice, these developments not only resulted in firms that were of a sufficient size to enable them to provide police station legal advice on a $24 / 7$ basis, but also meant that for many law firms providing such advice became a critical element of their business model, generating both a significant portion of their income and also providing an important source of new 'business'.

The structure of the criminal defence profession in the other three jurisdictions in the study was quite different. In Scotland, the right to custodial legal advice was introduced as recently as 2010, and whilst in the Netherlands the right to preinterrogation legal advice has been in existence for some years, as noted above the right to the presence of a lawyer during police interrogations still does not normally apply. In France, whilst the right to a pre-interrogation consultation with a lawyer had been in place for nearly two decades, ${ }^{72}$ the right to have a lawyer present during an

70 See, for example, M. McConville and J. Hodgson, op. cit.; M. McConville, J. Hodgson, L. Bridges and A. Pavlovic, op. cit.; and D. Brown, PACE Ten Years On: A Review of the Research (London: HMSO, 1997).

71 For an account of these developments, see E. Cape, “The Rise (and Fall?) of a Criminal Defence Profession" [2004] Criminal Law Review 401.

72 Introduced in 1993, suspects were then permitted a 30 minute consultation 20 hours after the start of their detention; in 2000 this consultation was permitted from the start of detention. 
interrogation had only recently been introduced. Although in the Netherlands and Scotland there is a well-established criminal defence profession, lawyers tend to operate in the context of smaller firms than in England and Wales, and in those jurisdictions and in France, they had not developed in-house organisational structures that enabled them to ensure that a lawyer is available to attend a police station at short notice. Generally, we found that police station work was regarded neither as an important source of income nor a significant source of work. Court work was prioritised, and within firms there was little evidence of rotas or other mechanisms being utilised to cover police station attendance outside of office hours.

Whilst such business and structural factors - which may change over time as the right to custodial legal advice 'beds down' and lawyers adjust their organisational arrangements - explain some of the differences in the delivery of custodial legal advice and assistance as between England and Wales and the other three jurisdictions, it does not explain the differences between those jurisdictions. Most starkly, as noted earlier, Scottish lawyers almost never attended the police station in person, whereas they did so more frequently in the Netherlands and even more so in France. Scottish lawyers explained their reluctance to attend police stations by reference to the right to silence - since suspects have a right to silence, it is enough to advise suspects on the telephone to exercise the right. ${ }^{73}$ However, in France and the Netherlands, the law also provides for an unqualified right to silence. ${ }^{74}$ In common with lawyers in the Netherlands, Scottish lawyers were also sceptical, in the absence of an obligation on the police to provide pre-interview disclosure, that they had a valuable role to play in advising clients at the police station. Lawyers in England and Wales did not have the same attitude even though the obligation regarding police disclosure was similarly limited. ${ }^{75}$ Lawyers in the Netherlands are, of course, restricted by the fact that they cannot normally attend police interrogations, but this is not the case in Scotland. Furthermore, whilst in the Netherlands and France there are significant limitations

73 This explanation should be treated with caution, since in the research sample only $16 \%$ of suspects did remain silent in police interrogations. It may be that it is a rationalisation for a reluctance resulting from other factors, such as levels of remuneration or the fact that law firms are not organised so as to facilitate police station advice in person. Lawyers in Scotland, also cited the corroboration rule as a reason why silence was generally the best course of action and so usually advised.

74 Although in the Netherlands only $7 \%$ of the observed sample of suspects remained silent, and researchers observed the police adopting strategies to undermine the right; in France, none of the (small) sample of suspects remained silent, and interviews with both police officers and lawyers suggested that exercising the right to silence can have adverse consequences for the suspect both at the investigative stage and subsequently.

75 Although in practice, in cases where the suspect had a lawyer, the police did normally provide some pre-interview disclosure to the lawyer. Note that the EU Directive on the right to information in criminal proceedings, Article 6, which provides for some pre-interview disclosure, came into effect on 2 June 2014, after the research project was completed. In England and Wales, PACE Codes of Practice $\mathrm{C}$ and $\mathrm{H}$ were revised, as from that date, to reflect the requirements of the Directive (Police and Criminal Evidence Act 1984 (Codes of Practice) (revisions to Codes C and H) Order 2014 SI No. 1237). 
on what lawyers can do in police interrogations, ${ }^{76}$ such limitations do not apply in Scotland.

One potentially significant factor informing the decision by lawyers whether to attend the police station in person is remuneration. For more than a decade following the introduction of the right of access to a lawyer in England and Wales, lawyers acting in legally-aided cases were paid by reference to time spent on a case, with enhancements for attending outside of office hours and when attending as a duty solicitor. Since 2007, lawyers have been paid a fixed fee, the level of which depends upon the geographical location of the law firm, and at the time the research was conducted it ranged between $€ 160$ and $€ 350,{ }^{77}$ with the possibility of being paid on an hourly basis in the case of exceptionally complex or prolonged investigations. The fee for providing advice by telephone was just over $€ 37$. The fee for work carried out at the police station was in addition to any fee for court work carried out. In France, the fee was $€ 300$ for advice and assistance provided during the first 24 hours of detention, and $€ 150$ if advice was provided during a further period of detention. In the Netherlands, lawyers were paid $€ 85$ for the first consultation prior to the first police interrogation, and an additional $€ 85$ for a second consultation, with a 50 per cent uplift at weekends. If, exceptionally, a lawyer attended an interrogation, the fee was either $€ 113$ or $€ 226$ depending on the seriousness of the suspected offence. The remuneration regime was more complex in Scotland. When the right to custodial legal advice was first introduced in 2010, solicitors were paid $€ 18$ for telephone advice, but the fee for attending a police station was normally subsumed in the fee paid in respect of representation at subsequent court proceedings. This was replaced by complex interim arrangements in July 2011, under which the fee for police station advice and assistance exceeding two hours (including travel time), or which was carried out between $10.00 \mathrm{pm}$ and $7.00 \mathrm{am}$, was not subsumed in the court fee. If not subsumed, the fee paid was calculated at the rate of $€ 57$ per hour (with an enhancement if carried out between $10.00 \mathrm{pm}$ and $7.00 \mathrm{am})$.

Given the variations in the basis for remuneration it is not possible to carry out a direct comparison between the financial incentives for providing police station advice across the different jurisdictions. In any event the utility of such a comparison is limited without knowing how the fees relate to remuneration rates for other work carried out by lawyers which may compete in terms of the priority lawyers are likely to place on the work. Their comparative utility is also limited without information on the time spent by lawyers in providing police station legal advice and assistance. However, it is notable that in Scotland, where lawyers were most reluctant to attend police stations in person, the remuneration scheme was unlikely to encourage personal attendance given that the hourly fee was relatively low and that, both before and after the changes in 2011, attendance at a police station would often not result in any extra

\footnotetext{
$76 \quad$ See text to n. 101 and n. 102.

77 All figures, where appropriate, have been converted into euros, and are approximate.
} 
payment to the lawyer. In the Netherlands, whilst the fee for the initial consultation may be regarded as comparatively generous, since the consultation is limited to 30 minutes, lawyers normally did not have the opportunity to earn an additional fee given the restrictions on attending police interrogations.

Another potentially important factor in the delivery of legal advice and assistance at police stations is the way in which duty lawyer schemes are organised. A police station duty lawyer scheme was in operation in all of the jurisdictions in the study, but whilst in England and Wales, and Scotland, they were standard schemes organised by the legal aid authority, in France and the Netherlands they differed depending upon the locality; in France they were organised by the local bar, and in the Netherlands by the Legal Aid Board. The method by which the police gave notification that a suspect requested a duty lawyer also differed between the jurisdictions. In England and Wales, some regions in the Netherlands, and in Scotland, contact with the duty lawyer scheme was via a central contact point, operated by the legal aid authority, which then notified the lawyer on duty. However, in the areas of the Netherlands where the research was conducted, the police contacted the duty lawyer directly, as did the police in one of the areas researched in France. In the other French area, a fairly large city, the local bar had appointed a duty lawyer co-ordinator, who was the contact point for the police. Generally, the various arrangements worked relatively smoothly in terms of ensuring that a duty lawyer was contacted; although in Scotland a minority of police officers said that they would prefer to contact the duty lawyer directly in order to save time, whereas officers in police stations in the Netherlands (where they had to contact the duty lawyer directly) resented having to "chase lawyers down" ${ }^{78}$

However, the various schemes had differing results in terms of ensuring that a duty lawyer attended the police station, and attended the police interrogation. In England and Wales, where attendance in person, and attendance at police interrogations, was the norm, all law firms with a legal aid contract were required to participate in the duty solicitor scheme. This required solicitors to be available during duty solicitor rota periods (with back-up arrangements during busy times), and the contract contained provisions - applicable to both duty solicitors and solicitors acting for their own clients - the thrust of which was that solicitors were normally expected to attend the police station in person when there was to be an interrogation, and to attend such interrogations. Failure to comply could, ultimately, result in termination of the contract. In Scotland participation in the duty lawyer scheme was also mandatory for lawyers doing legal aid work, but the terms of the scheme were clearly not effective in ensuring personal attendance by lawyers. In the Netherlands, the duty lawyer scheme required lawyers to respond to calls between $7.00 \mathrm{am}$ and $8.00 \mathrm{pm}$ on the duty day (and outside these hours for certain serious offences or where there was an urgent need to interview the suspect), but our researchers found that the duty lawyer did not always respond, even before the $8.00 \mathrm{pm}$ cut-off point. There were a

$78 \quad$ J. Blackstock, op. cit., p. 268. 
number of reasons for this, including the fact that on entering a police station the police took mobile telephones away from lawyers (so that they were unaware of calls for assistance, even in respect of suspects held in the same police station), and the fact that only one duty lawyer was on duty at any one time, and during busy times it was impossible for them to respond to all requests for assistance within the two-hour time limit. In France, personal attendance at the police station was mandatory for duty lawyers, and this appeared to be effective in ensuring their attendance.

The success of the French duty lawyer scheme in ensuring personal attendance came at a cost in terms of expertise. All of the lawyers in the local Bar area were obliged to sign up for the duty lawyer rota, and there was neither a competence, nor a training, requirement. ${ }^{79}$ As a result, duty lawyers did not always have (any, or sufficient) experience in criminal defence work, even in the larger city in the study, and this was very evident in some of the cases observed.$^{80}$ In the Netherlands, there is a fairly welldeveloped criminal bar, but the competence requirements were fairly minimal: duty lawyers were required to attend a one-day course, accompany a lawyer to the police station on six occasions, and handle at least 10 cases per year. In England and Wales, by contrast, all solicitors and representatives providing legally-aided police station advice were required to possess a specialist police station qualification, ${ }^{81}$ and duty lawyers had to conduct at least 24 police station cases per year. It is also worth noting that whilst the criminal legal aid contract in England and Wales normally required the law firm (but not necessarily the individual solicitor) to continue with a case in which they first acted at the police station through to completion of the proceedings, in France and the Netherlands advice and assistance at the police station was treated as a discrete event, so that if court proceedings ensued, the accused was likely to be represented by a different lawyer and law firm.

\section{THE ROLE OF DEFENCE LAWYERS AT THE INVESTIGATIVE STAGE}

Whilst the EU Directive on the right of access to a lawyer imposes a duty on Member States to ensure that suspects and accused persons have the right of access to a lawyer "so as to allow the persons concerned to exercise their rights of defence practically and effectively", 82 it does not spell out the role of the lawyer at the investigative stage. The Directive does contain guarantees regarding confidential lawyer/client consultations prior to interrogation, the right to have a lawyer present and to participate effectively during interrogations, and the right of the lawyer to attend investigative acts such as

\footnotetext{
79 Some rudimentary training was organized at a local level in the larger of our research sites, where a centralized duty rota was in operation, staffed by a co-ordinator.

80 See, for example, J. Blackstock, op. cit., pp. 92 and 398-399.

81 J. Blackstock, op. cit., p. 78.

82 Article 3(1).
} 
identity parades, ${ }^{83}$ but does not indicate what the lawyer could, or should, do. The primary rationale for custodial legal advice and assistance adopted by the ECtHR is to give effect to the privilege against self-incrimination and the right to silence, in particular by preventing coercion or oppression, ${ }^{84}$ but the Court has not indicated how this might be achieved. The nearest the ECtHR has come to defining, more broadly, the role of the lawyer is in the case of Dayanan $v$ Turkey in which the Court held that the principle of equality of arms requires that a suspect be afforded the complete range of interventions, including at the investigative stage, that are inherent to legal assistance, such as discussion of the case, instructions by the accused, the investigation of facts and search for favourable evidence, preparation for interrogation, the support of the suspect and review of the conditions under which the suspect is detained. ${ }^{85}$

In the research we examined both how lawyers approached their role when attending upon clients at police stations, and also how they acted during police interrogations. Overall, lawyers in all four jurisdictions were interrogation focused. Generally, where lawyers did attend the police station they did not do so until shortly before the interrogation and concentrated, in the consultations with their clients, on the upcoming interrogation. On the whole they did not deal with other needs of their clients, or other evidence-gathering aspects of police investigations, nor did they seek actively to verify or to challenge the lawfulness of the detention or begin any casebuilding. Most lawyer/client consultations were relatively short: an average of less than 15 minutes in Scotland (on the telephone), 20 minutes in France, 21 minutes in the Netherlands, and 26 minutes in England and Wales. Indeed, some lawyers regarded it as a virtue that they were able to keep consultations short. ${ }^{86}$ In the majority of cases there was only one consultation, although a second consultation was conducted in 40 per cent of cases observed in England and Wales, and just under 20 per cent in the Netherlands. Thus the 30 minute limit on consultations in France and the Netherlands did not appear to limit lawyers' practice. It might be that the restrictions on the number of consultations in France (normally limited to one) did encourage lawyers to time their attendance to shortly before the interrogation, although since a similar pattern was found in the other jurisdictions where there was no such limitation, it was unlikely to have been a significant factor. Perhaps of greater influence was the fee structure, the other professional demands on lawyers, and a reluctance to wait around at (or to travel to and from) police stations.

Article 3(3).

84 Salduzv Turkey, op. cit., para. 54; ECtHR 1 April 2010, Pavlenko v Russia, No. 42371/02, para. 101.

85 ECtHR 13 October 2009, No. 7377/03, para. 32.

86 M. McConville and J. Hodgson, op. cit. found that $49 \%$ of consultations lasted under ten minutes. What this average concealed was the very different practices between firms: some were routinely longer consulting with the client, whilst some high volume practices were "peremptory in their dealings with clients and appeared to want private consultations over as quickly as possible" (p. 53). 
Advice to suspects on how to respond in police interrogations cannot be divorced from the interrogation context, including the way in which police interrogation is regulated (including the length of interrogations and the length of detention), the police approach to interviewing, whether or not the lawyer may be present and any limitations on their ability to intervene, the implications of exercising the right to silence, and whether the interrogation is electronically recorded. England and Wales is the only one of the four jurisdictions where the law permits adverse inferences to be drawn from 'silence', although in France and the Netherlands in particular, 'silence' can have adverse consequences in practice, such as prolonging detention. The police in the Netherlands stood out as taking a particularly assertive approach to trying to undermine the exercise of the right to silence. Only in England and Wales are police interrogations routinely electronically recorded. In the Netherlands and Scotland some interrogations are electronically recorded, but generally in those jurisdictions, and in France, they are recorded in writing (either in long-hand or on computer).

Paramount amongst these variables, however, is the extent of police disclosure of the evidence regarding the suspected offence. Whilst in England and Wales, the police were observed routinely to provide at least some disclosure to the lawyer acting for a suspect (but not to unrepresented suspects), ${ }^{87}$ this generally did not happen in the other jurisdictions. Where a lawyer has not been given information about the evidence regarding the suspected offence, this will inevitably restrict their ability to provide their client with informed advice prior to interrogation. The lack of disclosure was used by some lawyers, notably in Scotland, as a reason for not attending interrogations, although others saw the interrogation as a way of finding out more about the police case. The reluctance on the part of the police to provide disclosure should change, at least to some extent, given the obligation in the EU Directive on the right to information for Member States to ensure that suspects are provided, before being interviewed, with at least a description of the facts including, where known, the time and place of the suspected offence, sufficient to "safeguard the fairness of the proceedings and allow for an effective exercise of the rights of defence". ${ }^{88}$ The Directive came into force after the fieldwork was completed, but some lawyers interviewed recognised that it has the potential to change both the police approach to interrogations, and their own role in them.

We found that the role played by lawyers in police interrogations differed significantly as between the four jurisdictions. In France and the Netherlands, lawyers almost never intervened in the observed interrogations, except at the end when they were invited by the interrogating officer to put questions or to comment. ${ }^{89}$ Lawyers

87 Which is related, in part, to the fact that inferences from 'silence' are less likely to be drawn if no, or limited, disclosure is provided. See, for example, $R v$ Roble [1997] Crim LR 449.

88 Article 6(1) and Recital 27. In England and Wales, for example, revised Codes of Practice $\mathrm{C}$ and $\mathrm{H}$ were introduced with effect from 2 June 2014, containing increased obligations regarding pre-interrogation disclosure. See, in particular Code C, paras. 3.4(b) and 11.1A, and Note for Guidance 11ZA.

89 Relatively few interrogations conducted in the presence of a lawyer were observed in these jurisdictions, but the lack of intervention by lawyer was confirmed in interviews with both lawyers and police officers. 
did not intervene even where it would clearly have been in the interests of their client to do so. For example, in one interrogation in France the lawyer remained silent when the interrogating officer, on numerous occasions, implied that the lawyer would agree with his opinion that it was in the best interests of the suspect to confess. ${ }^{90}$ Similarly, in the Netherlands we observed an interrogation where the lawyer remained silent even though the suspect was subjected to significant pressure to admit that he had engaged in sex with a minor. ${ }^{91}$ In Scotland, we were not able to observe interrogations conducted in the presence of a lawyer and, as noted earlier, lawyers normally do not attend them. Whilst guidelines issued by the Lord Advocate and a manual issued by the Association of Chief Police Officers in Scotland suggest an active role for lawyers, interviews with lawyers indicated that historically the police objected to interventions by lawyers. As one Scottish lawyer told us, "In the past I wouldn't [intervene] and wasn't allowed [to]". ${ }^{92}$ In the observed interrogations in England and Wales, the lawyer intervened in almost all of them, and in three observed interrogations the lawyer intervened on more than ten occasions. ${ }^{93}$ Most interventions involved the lawyer in giving advice and/or assistance to their client, for example, prompting them to respond or not to respond to particular questions, to check that the client understood the question, or to offer them support. Lawyers also intervened to provide information favourable to the client, and to challenge irrelevant questions, or questions prompting answers that were outside their client's knowledge.

What may explain the differences that we observed? It is important to remember that in France, the Netherlands and Scotland, the presence of lawyers in police interrogations is a relatively new phenomenon. The police are used to being able to conduct interrogations without 'outside' interference, and lawyers have not yet developed a clear understanding or articulation of what their role is, or could be, in interrogations. Much the same was found following the introduction of the right to have a lawyer present in police interrogations in England and Wales, ${ }^{94}$ but a number of factors were instrumental in effecting some change, including: judicial criticism of the passive role played by lawyers; ${ }^{95}$ similar criticism by the Royal Commission on

\footnotetext{
$90 \quad$ J. Blackstock et al., op. cit., p. 398.

91 J. Blackstock, et al., op. cit., p. 399.

92 J. Blackstock, et al., op. cit., p. 401.

93 The level of intervention was significantly greater than that found in research conducted in the early years following the introduction of the right of access to a solicitor (see, for example, M. McConville and J. Hodgson, op. cit. and M. McConville, M. Hodgson, J. Bridges and A. Pavlovic, op. cit.) but was more in line with the trend registered in subsequent studies (see, for example, L. Bridges and S. Choongh, Improving Police Station Legal Advice: The Impact of the Accreditation Scheme for Police Station Legal Advisers (London: Law Society's Research and Policy Planning Unit, 1998), and L. Bridges, E. Cape, P. Fenn, A. Mitchell, R. Moorhead and A. Sherr, Evaluation of the Public Defender Service in England and Wales (London: Legal Services Commission, 2007).

94 See M. McConville and J. Hodgson op. cit., and M. McConville et al., op. cit. See also D. Brown op. cit., pp. 115 - 118 for a summary of relevant research.

In particular, the Court of Appeal in Rv Paris, Abdullahi and Miller (1993) 97 Cr. App. R. 99.
} 
Criminal Justice; ${ }^{96}$ the adoption of the police station accreditation scheme; ${ }^{97}$ the articulation by the Law Society of an 'active defence' approach; 98 and the inclusion of a positive description of the lawyer's role in PACE Code of Practice C. ${ }^{99}$ Although police officers observed in England and Wales did not necessarily like interventions bylawyers, and some expressed a certain apprehension about conducting interrogations in the presence of a defence lawyer, we observed no case where the police interrogator objected to an intervention by the lawyer.

In France and the Netherlands, by contrast, the police were reluctant to permit interventions by lawyers and, where they did occur, reacted assertively if not aggressively. As one Dutch police officer commented, "I have no problem with the lawyer at the interview. The rule is, he cannot chip in during the interrogation. If he does, I immediately stop the interview and have the suspect taken back to his cell" ${ }^{100}$ The police in these jurisdictions were bolstered in this approach by provisions in the French Criminal Procedure Code, ${ }^{101}$ and by instructions issued by the Dutch Public Prosecutor's Office, ${ }^{102}$ which explicitly restrict intervention by lawyers during interrogations. In France, the police may submit an 'incident report' to the local Bar co-ordinator if they believe the lawyer to be obstructing the interview, and both police officers and lawyers said that such reports were rather common. ${ }^{103}$

\section{OCCUPATIONAL CULTURES}

Our study, confirming the findings of earlier empirical work, demonstrates that whilst clear and precise legal regulation of suspects' rights and the processes of administering them are key to effective legal reform, they are not enough. Legal procedures alone cannot effect shifts in behaviour, practices and cultures. There are broader and more entrenched factors that have the potential to assist or to undermine the process of change. The legal culture into which the reform is received is one important factor in understanding how the same ECtHR decision (for example, Salduz) can produce quite different legal outcomes in different jurisdictions. In countries in which procedures have been characterised by judicially supervised investigations, the defence lawyer's

\footnotetext{
96 RCCJ, Report, Cm 2263 (London: HMSO, 1993), paras. 46 - 64.

97 And the publication by the Law Society of a training programme, first published as Police Station Skills for Legal Advisers (London: The Law Society, 1994).

98 First published as R. Ede and E. Shepherd, Active Defence: A Solicitor's Guide to Police and Defence Investigation and Prosecution and Defence Disclosure in Criminal Cases (London: The Law Society, 1997).

99 See PACE Code C, Note for Guidance 6D, which sets out the role of the lawyer, and the circumstances in which a lawyer may intervene.

100 J. Blackstock, et al., op. cit., p. 402.

101 Article 63-4-3 CPP.

102 Aanwijzing rechtsbijstand politieverhoor 2010.

103 J. Blackstock et al., op. cit., p. 404.
} 
role has never developed to the extent seen in accusatorial models of procedure, ${ }^{104}$ and so the requirements of Salduz represented a greater challenge to the pre-trial distribution of roles. More generally, the development of Article 6 ECHR fair trial rights and the EU programme of procedural safeguards for suspects, is understood to reflect a more accusatorial procedure that does not sit easily with the legal traditions of countries such as France and the Netherlands. In England and Wales, a country with a more adversarial procedural tradition, the place of the lawyer as part of the due process protections of the accused is more established. However, that is not to say that the initial introduction of custodial legal advice was well received even there. Salduz did not have the same impact in England and Wales as in many other countries, as suspects have been entitled to legal assistance before and during police interrogation since the PACE 1984 was introduced in 1986. However, resistance to the introduction of custodial legal advice under PACE, especially on the part of police officers, was in similar terms to that seen in France in $1993,{ }^{105}$ when suspects were first permitted to consult with a lawyer during police custody, and most recently in the Netherlands and elsewhere, where access to a lawyer for suspects has been introduced for the first time. Whilst the more accusatorially styled safeguards developed through the jurisprudence of the ECtHR and the EU programme of measures may be more disruptive to the legal procedural traditions of jurisdictions that have favoured centralised models of criminal investigation, there is a universal resistance on the part of police and many prosecutors, to the strengthening of suspect's rights. ${ }^{106}$ In this final section, we examine police and lawyers' perceptions of custodial legal advice in the four jurisdictions in our study, in order to highlight the broader context in which the new EU measures will be received and how they might be made effective in practice.

Most police officers across all of the jurisdictions in the study regarded the lawyer's role in adversarial terms, as someone representing the interests of the suspect, which they in turn considered as being necessarily in opposition to the interests of an effective investigation. This view was strongest amongst younger officers and in those jurisdictions where the right had been recently introduced. Among more experienced police officers and where the rights had been in existence for some time, there was less hostility to the lawyer's role. Typically, the strengthening of suspects' rights was described as tipping the balance too far towards the accused and disadvantaging the victim. This characterisation of suspects' rights is problematic. It assumes that due process protections are good for the suspect and bad for the investigation and for victims of crime. It fails to recognise that such safeguards are designed to ensure fairness, procedural integrity and evidential credibility. These are, of course, also the

104 See J. Hodgson, (2002a) "Constructing the pre-trial role of the defence in French criminal procedure: An adversarial outsider in an inquisitorial process?” International Journal of Evidence and Proof 6(1) 1-16, and the sources noted in n. 36.

105 See J. Hodgson, (2002) op. cit.

106 This view is well represented in film and television depictions of criminal justice. See http://blogs. warwick.ac.uk/jackiehodgson/entry/the_wire_and/ (last accessed on 19 November 2014). 
aspirations of an effective investigation producing reliable evidence, which in turn benefits the victim by ensuring a reliable case outcome. This deep-seated belief is something that can be challenged through training, in an attempt to ensure that officers understand the rationale of safeguards and so 'buyin' to their effectiveimplementation. ${ }^{107}$

If police officers remain hostile to the utility and even the legitimacy of safeguards such as the right to legal assistance, they are more likely to employ rights-avoidance strategies such as those witnessed in the early post-PACE years in England and Wales. As noted earlier, in all jurisdictions apart from England and Wales we observed officers using suspects' preoccupation with being released from custody as soon as possible as a way of encouraging them to waive their right to a lawyer. ${ }^{108}$ Another strategy is for suspects to be questioned as 'volunteers' or witnesses in order to avoid the safeguards that attach to those classed as 'suspects'. ${ }^{109}$ This has been recognised explicitly in the recent French reform of the audition libre. In the past, those questioned as 'volunteers' were not regarded as being deprived of their liberty and thus not entitled to legal assistance. The reform will ensure that a person questioned - who is in practice a suspect, but who is detained under a different procedure to avoid the regulation imposed by the garde à vue - will be entitled to legal assistance in order to comply with the Directive on access to a lawyer. ${ }^{110}$

There are also practical factors that feed into police occupational culture and the generally negative views of the impact of custodial legal advice. Police officers noted that the right to legal assistance created additional work for them in contacting lawyers (which could be difficult, depending on the efficiency of local duty lawyer arrangements), and as a result the process of creating a paper trail demonstrating compliance. The introduction of lawyers into the detention and interrogation procedure also diminishes police control over timing of the interrogation, as this cannot take place before the suspect has consulted with the lawyer, if requested. Police continue to assert that suspects are much more likely to remain silent if they have first spoken with a lawyer, although empirical evidence does not support this. Changes of this kind need to be managed in practice in order to avoid legal advice being perceived by police officers in wholly negative terms. In France and Scotland, the material conditions of police detention were also problematic - there was often insufficient space to allow for a dedicated consultation room and lawyers were often squeezed into makeshift offices.

107 For an account of the pilot training carried out as part of our research see J. Blackstock, et al., op. cit., Annex 1, also published separately as J. Blackstock, E. Cape, J. Hodgson, A. Ogorodova, T. Spronken and M. Vanderhallen, Inside Police Custody: Training Framework on the Provision of Suspects' Rights (Antwerp: Intersentia, 2014).

108 See n. 47 and related text.

109 Such rights-avoidance strategies are found in many countries. See, for example, E. Cape et al. op. cit., p. 584, and E. Cape and Z. Namoradze, op. cit., p. 446.

110 This will have a huge impact. Whilst there are some 380,000 instances of garde à vue each year, there are more than twice as many audition libre procedures, which are estimated at 800,000 each year. 
A minority of police officers (especially in England and Wales) was more positive, or at least neutral, regarding the right to legal assistance. They recognised that lawyers did not hinder the investigation and, in many instances, may have a beneficial impact by ensuring a thorough and better investigation, persuading suspects to be more co-operative, more willing to speak once the nature of the charges or the evidence was explained to them, or more willing to accept an out-of-court case disposal. This more positive view of lawyers was based on the perceived benefits to the progress of the investigation, rather than the legitimacy of protecting suspects' rights per se.

The barriers to effective implementation of the right of access to a lawyer do not solely result from police occupational cultures - the working practices and attitudes of lawyers also inhibit access to legal advice and assistance by suspects detained by the police. Assisting suspects at the police station is quite different from trial or officebased work. It allows for little or no preparation; it requires the lawyer to negotiate with the police over issues such as information disclosure, pre-trial release, charge and the method of case disposition; it requires the lawyer to gather the facts of the case quickly and then advise a client (who they have often met for the first time) in a short space of time; the start and end time of custodial legal advice is unpredictable and attendance is often required during unsocial hours; and the interrogation must be closely followed in order that the lawyer may intervene if irrelevant or inappropriate questions are posed. And yet, as the ECtHR has recognised, what happens during the police interrogation of a suspect is likely to have a determinative effect on the outcome of the case:

... the Court underlines the importance of the investigation stage for the preparation of the criminal proceedings, as the evidence obtained during this stage determines the framework in which the offence charged will be considered at the trial. ${ }^{111}$

For these reasons, it is crucial that lawyers take seriously the suspect's right to legal assistance; not simply as an opportunity to expand their professional experience and business, but as a key opportunity to influence the course of the proceedings. Advising suspects requires a high level of legal knowledge and skills and, importantly, a clear idea of what the lawyer's role is.

The experience in England and Wales in the early period following the introduction of the right of suspects to legal advice was that lawyers failed to grasp the importance of custodial legal advice. Instead, many used it as a way to expand their client-base and to provide a steady stream of income. Work was delegated to a variety of nonlegally qualified clerks and independent agencies employing former police officers. ${ }^{112}$ Many suspects were poorly served - on paper they appeared to benefit from legal assistance, but they did not receive anything that might properly be termed 'legal advice'. These failures went beyond misplaced practices of systematic delegation.

$111 \quad$ Salduzv Turkey, op. cit., para. 54.

112 See, in particular, M. McConville et al. (1994), op. cit., esp. pp. 282-284. 
Lawyers themselves had no model of proactive defence; they simply managed the police station encounter as best they could, often leaving their client wholly unprotected. Perhaps the most famous example of such a failing is provided by the 'Cardiff Three' case, ${ }^{113}$ in which one of the accused (Miller, a young man with borderline learning difficulties) was subjected to 19 interrogations over five days. After denying the accusations of murder more than 300 times, he eventually confessed. Miller and his two co-accused were convicted of murder, but when the Court of Appeal judges listened to the audio-recordings of the interrogation, they allowed the appeal on the grounds of oppression. The judges were quite clearly shocked at the behaviour of the police:

We are bound to say that on hearing [the tape of Miller's interrogation], each member of this Court was horrified. Miller was bullied and hectored. The officers... were not so much questioning him as shouting at him what they wanted him to say. Short of physical violence, it is hard to conceive of a more hostile and intimidating approach by officers to a suspect. It is impossible to convey on the printed page the pace, menace, force and menace of the officer's delivery.

But they were also highly critical of the defence lawyer who had been present throughout the interviews:

In our view... the solicitor appears to have been gravely at fault for sitting passively through this travesty of an interview... the solicitor who sat in on the interviews seems to have done that and little else. ${ }^{114}$

This, and other critical court judgments, together with the report of the Royal Commission on Criminal Justice, which complained of a lack of clarity about the role of lawyers at the police station, ${ }^{115}$ led to the reforms described earlier, ${ }^{116}$ which were designed to ensure that lawyers were not only clear about their role, but also had the knowledge and skills to adopt an 'active' rather than a passive approach to police station work. Significantly, the government was persuaded to include in the PACE Code of Practice a statement that the lawyer's "only role in the police station is to protect and advance the legal rights of their client", together with a description of the circumstances in which the lawyer is permitted to intervene in interrogations. ${ }^{117}$

We do not seek to suggest that these developments resulted in all suspects in England and Wales receiving high quality legal advice and assistance, but we do argue

\footnotetext{
$113 \quad R v$ Paris, Abdullahi, Miller (1992) 97 Cr App Rep 99.

114 Paras 7, 9 and 24 of the judgment.

115 The Royal Commission on Criminal Justice, Report, Cm 2263 (London: HMSO, 1993), para. 60.

116 See text following n. 94.

117 "The solicitor may intervene in order to seek clarification, challenge an improper question to their client or the manner in which it is put, advise their client not to reply to particular questions, of if they wish to give their client further legal advice" (Code of Practice C, Note for Guidance 6D).
} 
that the range of reforms did both establish an 'active' role for lawyers providing advice and assistance at police stations, and helped to entrench it through a range of mechanisms. ${ }^{118}$ In France and the Netherlands, by contrast, passivity on the part of the defence lawyer is institutionalised by the legally sanctioned restrictions imposed on them. ${ }^{119}$ As one French lawyer explained to us:

We're just allowed to breathe and that's it, sometimes we even fall asleep. I'm not sure it's very useful... in terms of defence rights, it's useless: we are just decorative, like a vase on the table. ${ }^{120}$

These sentiments were echoed by a Dutch lawyer:

I cannot have any meaningful role at the interrogation. I cannot say anything. I can only intervene when the interrogator uses "illegal pressure", but these are extreme situations, [and] this practically never happens... ${ }^{121}$

In Scotland, whilst such restrictions are not imposed on defence lawyers, they have not taken up the opportunity to attend the police station in person, preferring telephone advice in most cases, and they have yet to embrace a more proactive defence lawyering model in respect of custodial legal advice.

It is likely that the role of the lawyer at the investigative stage will be strengthened in many countries as a result of implementation of the EU Directive on the right of access to a lawyer. This will pose new challenges for lawyers in terms of structure, organisation and modes of working. However, for the right of access to a lawyer to be a "practical and effective" right, it will be vital to ensure not only that lawyers are adequately trained in the knowledge and skills required for police station advice, but that the role of lawyers is properly recognised in law, regulations and professional guidance.

\section{CONCLUSIONS}

It is clear that the scope of custodial legal advice required under Salduz has been understood differently in different jurisdictions. These differences have extended to who may prevent or delay the suspect from receiving legal assistance and on what grounds; who is eligible to provide legal assistance; what choice the suspect has in

118 In addition to the Inside Police Custody research see, for example, L. Skinns, "The Right to Legal Advice in the Police Station: Past, Present and Future", Criminal Law Review, 2011; and V. Kemp, Bridewell Legal Advice Study: Adopting a 'whole systems' approach to police station legal advice" (London: Legal Services Research Centre, 2013). Cf., D. Newman, Legal Aid Lawyers and the Quest for Justice (Oxford: Hart Publishing, 2013).

119 See text to n. 101 and n. 102.

120 J. Blackstock et al., op. cit., p. 338.

121 J. Blackstock et al., op. cit., p. 407. 
selecting a lawyer; whether telephone advice is adequate; whether the lawyer/client consultation should be time-limited; whether lawyers may be present during interrogations; and whether they must remain passive or can intervene. The EU Directive on the right of access to a lawyer provides more detail than ECtHR jurisprudence on when the right of access applies, and does require that a suspect have a right to have their lawyer present during interrogation, and that the lawyer be able to 'participate effectively'. As an EU instrument, negotiations over the measure were informed by the impact assessment, which examined provisions in place across EU jurisdictions. There is also a three-year transposition period. Taken together, this gives the opportunity to Member States to plan implementation of the Directive, and introduce relevant laws, regulations and administrative provisions more rationally and with greater uniformity than has been the case following the Salduz decision. It should also enable the legal professions and legal aid authorities to take the steps necessary to help ensure that the right of access to a lawyer is a real and effective right.

It is clear that some jurisdictions will need to make significant reforms to their laws and procedures. The Netherlands, for example, will have to introduce a right for all suspects to have their lawyer present during police interrogations. However, quite apart from the fact that the Directive does not require legal aid to be available for custodial legal advice, in certain respects it also leaves Member States with a great deal of discretion, and this is where major difficulties may lie. The success of the Directive as implemented in practice will, as we have discussed, depend on a variety of factors, depending on whether states choose to make the minimum changes necessary to ensure formal compliance, or they embrace the programme of safeguards more enthusiastically. It is important that where rights under the EU Directive are to be transposed in accordance with national procedures, that these do not undermine the wider objectives. For example, whilst suspects must have a right to consult with their lawyer in private prior to interrogation, states "may make practical arrangements concerning the duration, frequency and means of such communication", provided that they do not "prejudice the effective exercise or essence of the right". ${ }^{122}$ Should lawyer/client consultations be time-limited or limited in number, as in France and the Netherlands? A consultation of 30 minutes may, in a particular case (especially if the person is suspected of a serious offence, or is vulnerable), be insufficient to enable the lawyer to discover the suspect's version of events, to check on basic background and other information that might affect the suspect's position, and then to advise on how to approach the police interrogation. ${ }^{123}$ Effective participation of a lawyer in police interrogations is explicitly subject, in the Directive, to it being "in accordance with procedures under national law", provided that they do not "prejudice the effective

\footnotetext{
122 EU Directive on the right of access to a lawyer, Recital 23.

123 A limit of 30 minutes does not allow for the kind of legal assistance envisaged in Dayanan $v$ Turkey, op. cit.
} 
exercise and essence of the right concerned". ${ }^{24}$ Do the restrictions to be found in France and the Netherlands fall within this qualification? The Salduz line of jurisprudence suggest that such restrictions are not permissible, but it may take some time before this is definitively established.

The ability of lawyers to advise suspects in police custody promptly and effectively cannot be divorced from a range of other factors such as the procedure by which suspects are notified of their right of access at a time and in a manner that enables them to make an informed decision about whether to exercise the right, the provision of sufficient remuneration and the establishment of duty lawyer schemes that ensure that lawyers are willing and able to attend police stations, and the disclosure of sufficient information by the police to enable lawyers to provide appropriate and effective legal advice to their clients. These are covered, to a certain extent, by the EU Directive on the right to information, and the proposed Directive on provisional legal aid. However, if the right of access to a lawyer is to be effective, it will require Member States to fully embrace the whole package of reforms designed to improve procedural rights.

A further, and perhaps more challenging, hurdle is to change the culture of the police, lawyers, prosecutors and judges, so that they understand and subscribe to the value of procedural rights. If lawyers are to assist suspects effectively, they require sufficient expertise and skill to engage actively in the defence of the accused. This requires training of lawyers in police station work and ensuring that duty lawyer schemes are staffed by lawyers with appropriate levels of competence and experience. Lawyers must embrace police station work as the beginning of the defence case - the trial starts at the police station - even when, in practice, another firm or lawyer may subsequently represent the accused. Lawyers must help prepare their clients for police interrogation, but also go beyond this and deal with other investigative measures and the affective needs of suspects. Police officers and, indeed, prosecutors and judges, must accept the legitimacy of the procedural rights of suspects and understand the ways in which such rights can ensure the credibility and reliability of investigative processes, rather than regarding the defence role as antithetical to effective investigation and fair trial. Without this shift in cultural and professional attitudes, police officers are liable to try to undermine procedural safeguards, and prosecutors and judges are liable to facilitate such actions.

For many jurisdictions, the introduction or strengthening of custodial legal advice will represent a significant change, not only to the process of detention and interrogation of suspects, but to the very understanding of the investigative process. Changing the law will not necessarily result in changes to attitudes or working practices. More work will have to be done to enable police officers to understand the value of due process protections to effective and reliable investigation, and to fair trial. Lawyers too will need to prepare for the consequences of greater and more

124 EU Directive on the right of access to a lawyer, Article 3(3)(b). 
challenging demands on their time and professional conduct. In our study, we found that training police and lawyers alongside one another was successful in enabling each to understand better the role of the other. This reduced friction and promoted greater awareness of the practical difficulties each faced, as well as exploding myths about what lawyers do. ${ }^{125}$

Many of the challenges in implementing the EU Directive on the right of access to a lawyer have, in effect, already been faced in England and Wales where, as the research demonstrated, significant progress has been made in ensuring that suspects in police custody do have effective access to legal advice and assistance. Many of the difficulties in implementing the right experienced in the other jurisdictions in the study were encountered in England and Wales following introduction of the right to a lawyer in the 1980s. The lessons learnt, whilst not directly transferable, could contribute to the effective implementation of the Directive, not only in those jurisdictions but also in all EU Member States. Whether those states will be willing to learn from one that has not opted-in to the Directive ${ }^{126}$ remains to be seen, but since both law and practice in England and Wales is largely compliant with the requirements of the Directive, it is to be hoped that the political stance of the current UK government will not inhibit that process.

Ensuring that procedural safeguards for suspects are clear and effective is more important than ever. In addition to the increasing levels of EU co-operation concerning the exchange of evidence, data and accused persons, the early stages of detention and investigation are increasingly important in determining the nature of case disposition. Jurisdictions across the EU are adopting discretionary justice procedures, administered at increasingly early stages of the process, which avoid the scrutiny of trial altogether. The evidence provided by the suspect under interrogation is the centrepiece of the trial process as, perhaps, never before.

\footnotetext{
125 See n. 107.

126 See n. 19.
} 